\title{
Urgensi Pembentukan Undang-Undang Fintech Di Indonesia: Harapan Dan Realita Di Era Pandemic Covid-19
}

\author{
Didik Irawansah ${ }^{1 *}$, Wardah Yuspin ${ }^{2}$, Ridwan $^{3}$ Nasrullah $^{4}$ \\ 1, 2, Magister Ilmu Hukum Universitas Muhammadiyah Surakarta, Surakarta, Indonesia \\ 3, 4, Program Studi Ilmu Hukum STIH Muhammadiyah Bima, Kota Bima, Indonesia \\ *E-mail: didikirawansah@gmail.com
}

Dikirim: 25/06/2021

\begin{tabular}{l}
\hline Info Artikel \\
\hline \\
Keywords: \\
Urgency; Fintech Act; \\
Protection; \\
Consumer; Indonesia.
\end{tabular}

Kata Kunci:

Perbuatan Tercela,

Pemakzulan

Presiden/Wakil

Presiden, Hukum

Pidana.

\section{Direvisi: 01/12/2021}

Dipublikasi: 31/12/2021

\section{Abstract}

The growth of Fintech in Indonesia is very rapid, this condition is directly proportional to the legal problems that arise, the legal policy of regulation and protection of Fintech is still focused on the OJK, while the OJK still has many weaknesses in the implementation of supervision and protection of fintech activities, especially in the era of the covid pandemic. -19. The purpose of this study, first, by outlining the legal regulations issued by Bank Indonesia and the Financial Services Authority regarding fintech in Indonesia by looking at the legal weaknesses so that it is important to establish the Fintech Law. second, the urgency of the establishment of a fintech law on fintech consumer protection in Indonesia. Meanwhile, the importance of this research is that it will explain the development of the fintech industry in Indonesia, especially during the Pandemic, where the fintech industry experienced significant development so that this is an idea to provide a clear legal framework for the fintech industry. The research method used is normative juridical using library data and observations of fintech developments through library studies. Research findings show that so far fintech in Indonesia has used regulations contained in the POJK and PBI as the basis for implementing fintech, although it is felt that the regulations issued by POJK and PBI have not been able to provide maximum legal protection for the implementation of the fintech industry. so it is necessary to establish a law in order to provide legal protection for the development of the fintech industry now and in the future.

\footnotetext{
Abstrak

Pertumbuhan Fintech di Indonesia sangat pesat, kondisi ini berbading lurus dengan masalah-masalah hukum yang timbul, kebijakan hukum pengaturan dan perlindungan terhadap Fintech masih dinitiberatkan kepada OJK, sedangkan OJK masih terdapat banyak kelemahan dalam penyelenggaraan pengawasan serta perlindungan terhadap kegiatan fintech apalagi di era pandemic covid-19. Tujuan Penelitian ini Pertama, dengan menguraikan Peraturan Hukum Yang di Keluarkan Bank Indonesia dan Otoritas Jasa Keuangan tentang fintech di Indonesia dengan melihat sisi-sisi kelemahan hukum sehingga pentingya terhadap pembentukan UU Fintech. kedua, Urgensi Pembentukan UU fintech terhadap Perlindungan Konsumen fintech di Indonesia. Metode penelitian yang digunakan adalah Yuridis
} 
DOI:

10.47268/sasi.v27i4.581

Normatif dengan menggunakan data-data kepustakaan dan observasi perkembangan fintech melalui studi Pustaka baik dari sisi peraturan, buku yang relevan maupun jurnal-jurnal hukum yang berkaitan dengan objek yang diteliti. Hasil Peneitian menunjukan selama ini fintech di Indonesia menggunakan regulasi yang berada didalam POJK dan PBI sebagai dasar pemberlakuan fintech, meskipun dirasa regulasi yang di keluarkan Oleh POJK dan PBI ini belum dapat memberikan perlindungan hukum yang maksimal terhadap pelaksanaan industri fintech. sehingga perlu kiranya pembentukan Undang-undang agar dapat memberikan perlindungan hukum terhadap perkembangan industry fintech kini dan akan datang.

\section{A. PENDAHULUAN}

Pandemic Covid-19 menjadi masalah bagi seluruh Negara di dunia. ${ }^{1}$ Kondisi ini juga mendorong pemerintah Indonesia pada tanggal 31 Maret 2020 tahun lalu menetapkan Indonesia dalam Kedaruratan Kesehatan masyarakat terkait Pandemic Covid-19 dan kemudian menerbitkan kebijakan Pembatasan Sosial Berskala Besar (PSBB), ${ }^{2}$ sampai dengan tahun 2021 ini. Corona Virus Disease-19 (COVID-19) berdampak signifikan terhadap seluruh aspek kehidupan manusia di dunia, terutama di Indonesia yang memiliki wilayah yang sangat luas dan jumlah penduduk yang besar (sekitar 267 juta jiwa) dengan berbagai macam profesi ${ }^{3}$. Hal ini didasarkan karena Wabah Corona Virus Disease (Covis-19) menjadi problem secara global. Organisasi Word Health Organization (WHO) mencatat dari 196 Negara di Dunia, sebanyak 1.696.588 kasus terkonfirmasi positif Covid-19, dan dari jumlah tersebut sebanyak 105.952 dilaporkan meninggal dunia berdasarkan data tahun 2020. ${ }^{4}$ Sedangkan perkembangan Pandemic Covid-19 per 15 Maret tahun 2021, secara Global, sebanyak 103 Negara di dunia dan terkonfirmasi sebanyak 83.626.585 kasus terkonfirmasi positif Covid-19 dan dari jumlah tersebut sebanyak 2.094.136 dilaporkan meninggal dunia. Sedangkan di Indonesia sendiri tercatat 1.927.708. yang terkonfirmasi positif Covid -19 dan dari jumlah tersebut sebanyak 53.280 dilaporkan meninggal dunia. ${ }^{5}$ Kondisi ini walaupun ada penurunan dari tahun 2020 sampai dengan tahun 2021 penyebaran dan tingkat kematian akibat Covid-19 tidak menurun secara signifikan, kondisi ini membuat Negara-negara masih tetap tidak bisa beraktifitas secara normal dan masih menetapkan kebijakan PSBB termasuk Indonesia. Disamping itu juga Pandemic Covid-19 telah memberikan dampak cukup besar Bagi Perekonomian global dan perekonomian Indonesia. ${ }^{6}$

Pandemi Covid-19 pada perkembangan perekonomian secara global membawa pengaruh tidak hanya terhadap dunia ekonomi, namun juga berkorelasi terhadap aspek perkembangan hukum ${ }^{7}$. Upaya pemerintah untuk menjaga keselamatan masyarakat dan menjaga kestabilan ekonomi, sebagai akibat penyebaran COVID-19 di Indonesia ${ }^{8}$, pemerintah menerapkan suatu peraturan Pembatasan Sosial Berskala Besar (PSBB), hal ini sebagai suatu langkah pencegahan

1 Spoorthy, M. S., Pratapa, S. K., \& Mahant, S. (2020). Mental health problems faced by healthcare workers due to the COVID-19 pandemic-A review. Asian journal of psychiatry, 51, 102119.

2 Hairi, P. J. (2020). Implikasi Hukum Pembatasan Sosial Berskala Besar Terkait Pencegahan COVID-19. Info Singkat Bidang Hukum, 12 (April), 1-6.

3 Kunarso, K., \& Sumaryanto, A. D. (2020). Eksistensi Perjanjian Ditengah Pandemi Covid-19. Batulis Civil Law Review, 1(1), 33-46.

4 Hairi, P. J. (2020). Op.Cit.

5 Perkembangan Covid-19. https://covid19.go.id/ diakses Pada tanggal, 25 Juni 2021.

6 Nasruddin, R., \& Haq, I. (2020). Pembatasan Sosial Berskala Besar (PSBB) dan Masyarakat Berpenghasilan Rendah. SALAM: Jurnal Sosial dan Budaya Syar-i, 7(7), 639-648.

7 Saija, R., \& Sudiarawan, K. A. (2021). Perlindungan Hukum Bagi Perusahaan Debitur Pailit dalam Menghadapi Pandemi Covid 19. Batulis Civil Law Review, 2(1), 66-77.

8 Taun, T., \& Nugraha, A. (2020). Penerapan Hukum dalam Pemutusan Hubungan Kerja dan Kebijakan Bank Terhadap Debitur yang Terdampak Pandemi Covid-19. Batulis Civil Law Review, 1(1), 24-32. 
terhadap penyebaran Pandemic Covid-19, namun kebijakan ini berdampak besar pada perekonomian masyarakat, dampak yang cukup signifikan adalah menurunya penghasilan masyarakat sehingga mengalami kesulitan dalam memenuhi kebutuhan sehari-hari. ${ }^{9}$ Dengan demikian masyarakat mencari alternatif lain untuk mencukupi kebutuhannya dengan melakukan peminjaman di financial teknologi (Fintech) Peer To Peer lending. Indonesia, setelah ditetapkannya sebagai bencana nasional, pemerintah melakukan upaya-upaya guna mengurangi penyebaran Covid-19 dengan kebijakan-kebijakan hukum, baik berupa Peraturan Pemerintah maupun berupa Surat Edaran, dampak yang dialami oleh masyarakat lebih kompleks dengan kebijakan tersebut.

Sector-sektor yang terkena dampak meliputi sector ekonomi, Politik, pariwisata, dan lainnya. Kondisi diatas, yang berdampak sangat besar adalah disektor ekonomi. Di Indonesia kegiatan ekonomi yang marak dilakukan oleh masyarakat adalah pengajuan kredit. Pemberian kredit sendiri tidak hanya dilakukan pada sector perbankan tetapi juga dilakukan pada lembagalembaga pembiayaan, sebagaimana saat ini banyak diminati oleh masyarakat yaitu pinjaman berbasis online.

Di Indonesia, pinjam meminjam berbasis online dilakukan dengan menggunakan pinjaman secara online, hal ini dapat mempermudah masyarakat guna mengakses produkproduk keuangan yang dibutuhkan. Pinjam meminjam berbasis online mepermudah masyarakat karena tidak perlu bertemu secara langsung tetapi melalui aplikasi atau laman website, disamping kemudahan terhadap pinjam meminjam berbasis online, ternyata juga berdampak buruk pada masyarakat, terutama suku bunga yang tinggi dan tersebarnya data-data konsumen fintech serta adanya ancaman-ancaman dari berbagai penagih akibat gagal bayar.

Dampak terhadap covid-19 memaksa masyarakat mengurangi aktifitas tatap muka diperbankan secara tatap muka, dan mengharuskan beralih ke proses digital dan menggunakan jasa fintech peer to peer lending, data OJK ditahun 2020 menyebutkan transaksi di e-Commerce meningkat hingga $400 \%$ dimasa Pandemic Covid-19, sehingga ditahun 2021, akan semakin meningkat. Kasus yang timbul dimasyarakat sebagai akibat dari hadirnya fintech ada berbagai macam, seperti pengenaan pajak yang tinggi oleh entitas fintech, penagihan hutang yang tidak sesuai dengan prosedur, pengambilan data pribadi, tindak pidana pengancaman, bahkan dalam beberapa kasus diikuti oleh tindak pidana pelecehan seksual. Banyaknya kasus fintech baik yang bersifat illegal, maupun kasus fintech yang melakukan pelanggaran hukum terhadap hak konsumen sangat perlu mendapatkan perhatian pemerintah karena menyangkut masalah hidup banyak orang dalam semua lapisan sosial masyarakat, meskipun memang lebih banyak dialami oleh masyarakat sosial lapisan bawah. Hal ini tentu saja terjadi karena minimnya pengetahuan dalam bertaransaksi dengan menggunakan teknologi yang berkembang cukup pesat, juga disebabkan oleh mudahnya orang-orang tertarik melihat aplikasi pinjaman online yang menberikan iming-iming yang menggiurkan seperti proses pencairan pinjaman yang hanya memakan waktu 15 hingga 20 menit. Disamping itu, masyarakat Indonesia juga rendahnya minat baca sehingga mudah terjerat fintech yang illegal sebagaimana yang dipaparkan oleh UNESCO pada tahun 2016 yang lalu bahwa tingkat membaca orang Indonesia sangat memprihatinkan, hanya sekitar $0.001 \%$ yang artinya dari 1000 orang di Indonesia hanya 1 orang yang rajin membaca. Semetara sebagaimana diketahui, setiap website maupun aplikasi yang disediakan oleh entitas fintech sebelum masuk dan mendaftar kedalam website atau aplikasi tersebut selalu menampilkan dan memuat ternm and condition yang menjelaskan segala syarat pengguna dari aplikasi tersebut dan memuat hal-hal yang dapat diakses dan sebagainya.

Peraturan yang dikeluarkan oleh Otoritas Jasa Keuangan maupun peraturan Bank Indonesia dianggap masih bersifat administrasi, yang berarti bahwa dalam hal terjadinya pelanggaran hukum oleh Fintech, sanksi yang dapat diberikan sesuai dengan peraturan tersebut

9 Nasruddin, R., \& Haq, I. (2020). Op. Cit. 534|S A S V Vo1. 27 No.4, Oktober - Desember 2021 
tidak dapat melindungi semua hak konsumen. Hal ini karena dalam peraturan yang dikeluarkan oleh OJK, tidak memuat sanksi pidana maupun sanksi denda apabila terjadi pelanggaran oleh Fintech, sangsi maksimal yang dikeluarkan, hanyalah sanksi pencabutan tanda terdaftar dan pencabutan izin.

Fintech telah berkembang pesat diseluruh dunia, dalam beberapa tahun terakhir perkembangan fintech sangat berfariasi diberbagai Negara. Fariasi fintech ini mencerminkan perbedaan dalam perkembangan ekonomi dan struktur pasar keuangan global. Kondisi ini menunjukan semakin tinggi pendapatan suatu Negara dan semakin besar pula aktifitas kredit fintech. Volume kredit Fintech juga lebih besar di Negara-negara dengan regulasi perbankan yang tidak terlalu ketat. ${ }^{10}$ Perkembangan fintech diberbagai Negara dapat menimbulkan peluang sekaligus tantangan Tantangan saat ini sebagian besar pada Negara - Negara ini yaitu pada perlindungan konsumen dan investor, kondisi ini muncul kekhawatiran terhadap meningkatnya kerugian kredit fintech dan perilaku bisnis yang buruk di beberapa Negara tersebut.

Peran Negara sangat diperlukan salah satunya adalah kebijakan Pembentukan UndangUndang Khusus fintech sebagai upaya penyelesaian sengketa hukum di bidang financial technologi. Pada dasarnya kehadiran fintech diindonesia sangat bagus terutama memudahkan masyarakat kelas menengah dalam membutuhkan modal usaha yang didalamnya tanpa ribet dan/atau waktu lama, namun kondisi ini memiliki dampak yang cukup serius, terutama legalitas hukum nya, kondisi ini perlu ada kebijakan khusus pemerintah dalam penanganannya, terutama produk hukum khusus fintech berupa Undang-Undang tersendiri untuk mengakomodir baik dalam Perijinan, Pengaturan, Pengawasan, Penyelenggaraan serta pada perlindungan hukum terhadap kegiatan Financial Technology.

Pada industry 4.0, Permasalahan fintech cukup serius, terdapat banyaknya fintech yang illegal, ragam masalah hukum terjadi baik proses penagihanya dengan bahasa yang kasar, pelecehan seksual, Tingginya bunga pinjaman dan pencurian data nasabah. ${ }^{11}$ Dalam proses penegakannya, Kebijakan hukum hanya menitiberatkan pada OJK dalam melakukan Pengawasan. Peran Otoritas Jasa Keuangan dalam melakukan pengawasan dan perlindungan hukum dinilai kurang aktif sehingga didalamnya masih menimbulkan problem yang dapat berdampak pada inklusi keuangan. Serta masih lemahnya perlindungan hukum terhadap pengguna jasa fintech. ${ }^{12}$ Ini menunjukan atas lemahnya regulasi hukum, karena Indonesia sendiri belum ada UU Khusus Fintech, melainkan hanya aturan-aturan teknis yang dikelurkan oleh BI maupun oleh OJK. ${ }^{13}$

Salah satu alasan konsumen enggan menggunakan Fintech adalah karena fintech dianggap kurang aman lantaran tidak adanya regulasi yang memadai dalam memberikan perlindungan hukum dalam kegiatan fintech. ${ }^{14}$ Sedangkan tujuan Regulasi pada umunya adalah berusaha menyeimbangkan tujuan bersaing untuk mempromosikan inovasi, stabiltas keuangan, pemantaun pelaporan, kepatuhan serta perlindungan konsumen. ${ }^{15}$

Pertumbuhan financial technology sangat pesat, terhitung fintech yang terdaftar dan beijin

10 Claessens, S., Frost, J., Turner, G., \& Zhu, F. (2018). Fintech credit markets around the world: size, drivers and policy issues. BIS Quarterly Review September.

11 Johnson, P. S., \& Harefa, A. A. (2018). Financial Technology, Regulation and Banking Adaptation in Indonesia. Fundamental Management Journal, 3 (1), 1-11.

12 Benuf, K., Mahmudah, S., \& Priyono, E. A. (2019). Perlindungan Hukum Terhadap Keamanan Data Konsumen Financial Technology Di Indonesia. Refleksi Hukum: Jurnal Ilmu Hukum, 3(2), 145-160.

13 Yuking, A. S. (2018). Urgensi peraturan perlindungan data pribadi dalam era bisnis fintech. Jurnal Hukum dan Pasar Modal, 8(16), 1-27.

14 Batunanggar, S. (2019). Fintech Development and Regulatory Frameworks in Indonesia. Asian Development Bank Institute, 1014(1014), 1-12.

15 Allen, F., Gu, X., \& Jagtiani, J. (2020). A Survey of Fintech Research and Policy Discussion. Doi.org/10.21799/frbp.wp.2020.21.

$$
\text { 535|S A S Vol. } 27 \text { No.4, Oktober - Desember } 2021
$$


diindonesia sejumlah 146 perusahaan fintech per 4 Mei 2021 sedangkan fintech yang illegal sejumlah 338. ${ }^{16}$ Kondisi ini, Pemerintah semestinya diikuti dengan lahirnya peraturan perundang-undang yang memadai agar menyokongnya. Peraturan-peraturan ini agar memberikan keamanan bagi seluruh stakeholder terkait praktek financial. Peraturan-peraturan hukum yang sebelumnya ada masih sangat terbatas mengenai pengaturan dan perlindungan hukum terhadap transaksi fintech, menurut Deputi Komisioner Otoritas Jasa Keuangan Institute dan Keuangan Digital menyatakan bahwa fintech ini belum ada undang-Undangnya, dengan kondisi yang demikian maka perlu pembuatan Undang-Undang tentang fintech agar memperjelas kedudukannya. Hal ini menyangkut penjelasan mengenai fintech itu apa, kemudian cakupan komoditinya seperti apa, serta siapa saja yang mengaturnya, apa saja yang diharuskan dan dilarang, ini semua harus jelas. ${ }^{17}$

Menurut Deputi Komisioner Otoritas Jasa Keuangan, permasalah lain terkait financial technologi adalah belum ada peraturan yang dapat mengcover fintech konvesional maupun Fintech Syariah Indonesia. Ketua umum Asosiasi Fintech Syariah Indonesia (AFSI) Ronald Yusuf Wijaya meminta Otoritas Jasa Keungan (OJK) untuk membuat peraturan yang lebih umum terkait pengoperasian financial technologi. Menurutnya peraturan - peraturan ini belum bisa mengakomodir kebutuhan-kebutuhan dalam penyelenggaraan fintech. ${ }^{18}$

Hal yang sama yang disampaikan oleh Dewan Perwakilan Rakyat dalam pernyataannya menyatakan bahwa peraturan mengenai transaksi keuangan berbasis digital ini seperti fintech belum ada Undang-undangnya, dengan demikian, pengawasan industry fintech ini harus diawasi secara massif dan agresif oleh BI dan OJK. ${ }^{19}$ Peraturan yang berkaitan dengan transaksi financial technologi sampai saat ini memang belum diatur dibeberapa peraturanperaturan terkait baik dari Otoritas Jasa Keuangan (OJK) maupun Oleh Bank Indonesia (BI), dan/atau pada peraturan-peraturan lainnya.

Dewan Perwakilan Rakyat Indonesia (DPR RI), Kementrian Hukum dan Hak Asasi Manusia, Otoritas Jasa Keuangan (OJK), dan Bank Indonesia (BI) perlu segera memprakarsai dan merancang RUU fintech (RUU) untuk badan legislatif nasional 2021. Mendorong dan memberlakukannya agar Industry fintech Indonesia dapat memiliki legal framework yang kuat. OJK dan BI perlu segera membentuk badan alternative penyelesaian sengketa khusus sector fintech untuk memberikan langkah-langkah non litigasi. Merancang undang-undang fintech yang mengakomodir aspirasi dan partisipasi pemangku kepentingan terkait dengan tetap memastiakn implementasi yang realistis, proses legislasi perlu melibatkan antara lain, Kementrian Keuangan, Otoritas Jasa Keunagan (OJK), Bank Indonesia (BI), Asosiasi Fintech Indonesia (AFI), Asosiasi Fintech Pendanaan bersama Indonesia (AFSI), Bisnis Swasta, Public serta pemangku Kepentingan terkait lainnya.

Tidak adanya Undang-undang fintech tertentu yang masih berlaku jelas tidak menyurutkan niat para pelaku tekfin untuk melakukan pelanggaran hukum. secara berurutan, aktivitas tekfin illegal menyebabka perlindungan hukum yang tidak memadai bagi pihak-pihak yang rentan. Tanpa mitigasi yang tepat dan memadai, masalah ini dapat berdampak serius pada stabilitas keuangan. ${ }^{20}$

16 Daftar Fintech Berijin dan Terdaftar di OJK. https://www.ojk.go.id/id/kanal/iknb/financialtechnology/Default.aspx . diakses Pada Tanggal 20 Mei 2021.

17 Sari, F. (2019). Perjelas Landasan Hukum, Ojk Dorong Pembentukan Uu Fintech. Retrieved From Https://Keuangan.Kontan.Co.Id/News/Perjelas-Landasanhukum-Ojk-Dorong Pembentukan-Uu-Fintech.

18 Wulandhari, R. (2019). Afsi: Peraturan Ojk Belum Mewadahi Fintech Syariah. Retrieved From Https://Republika.Co.Id/Berita/Pwmq1n370/Afsi-Peraturan-Ojkbelum-Mewadahi-Emfintechem-Syariah

19 Hidayat, R. (2019). Dpr Terbuka Jika Industri Fintech Diatur Uu, Tapi... Retrieved From Https:/Www.Hukumonline.Com/Berita/Baca/Lt5c9e0b2aec3ed/Dpr-Terbuka-Jikaindustri-FintechdiaturUutap.

20 Chatterjee, S. (2019). Is data privacy a fundamental right in India? An analysis and recommendations from policy and legal perspective. International Journal of Law and Management, 61(1), 170-190.

$$
\text { 536|S A S V V 1. } 27 \text { No.4, Oktober- Desember } 2021
$$


Mengingat masalah yang sangat serius seputar tekfin dan kurangnya regulasi yang komprehensif untuk industry saat ini, Indonesia ssangat membutuhkan kerangka hukum yang baik dalam bentuk undang-undang. Kebijakan yang ada, peraturan bank Indonesia (PBI), dan peraturan otoritas jasa keuangan (POJK), hanya mengatur hal-hal teknis di industri sehingga kekuatan hukumnya sangat lemah. Selain sebagai pelindung hukum bagi industry tekfin, UU fintech juga berfungsi sebagai mitigasi hukum bagi pemangku kepentingan terkait yang mencegah berbagai potensi resiko. ${ }^{21}$ Fintech law ${ }^{22}$ dapat membantu menjaga stabilitas keuangan, memperkuat perlindungan konsumen. ${ }^{23}$, dan mendorong perkembangan ekonomi digital. $^{24}$

Banyak studi empiris telah menyelidiki masalah Financial Technology ini, ${ }^{25}$ dalam penelitian Rosenblum bahwa regulasi Khusus Fintech penting untuk di gagas hal ini, guna upaya perlindungan hukum terhadap konsumen pengguna fintech $^{26}$. Disisi lain juga dalam penelitian Jagtiani berpendapat yang sama bahwa regulasi khusus fintech penting, sebagai regulasi hukum yang dapat memberikan perlindungan hukum konsumen dan menjaga stabilitas keuangan serta dapat menciptakan perlindungan untuk inovasi fintech berikutnya. ${ }^{27}$

Sementara itu Magnuson, mengamati bahwa regulasi saat ini telah gagal memperhitungkan kebangkitan perusahaan teknologi keuangan dan perubahan mendasar yang mereka bawa keberbagai bidang, mulai dari cara kerja perbankan, hingga cara modal dikumpulkan, bahkan hingga dalam bentuk uang. Dari perubahan ini membutuhkan rekonseptualisasi yang kuat dari regulasi keuangan di era keuangan yang didukung teknologi. ${ }^{28}$ Lebih jauh, beberapa penelitian semuanya setuju bahwa mengatur fintech adalah yang paling penting di zaman sekarang ini, baik penelitian yang dikemukan oleh, Chatterjee tahun 2019, Penelitian yang dilakukan oleh Carmona, Dkk, 2018, ${ }^{29}$ Penelitian Arneret, at., tahun 2017, ${ }^{30}$ Penelitian Saksonova and Kuzmina-Merlino tahun 2017, ${ }^{31}$ serta Penelitian Treleven tahun $2015,{ }^{32}$ dalam beberapa penelitian yang diuaraikan tersebut oleh para peneliti, semuanya bersepakat bahwa pengaturan serta regulasi khusus Fintech perlu di atur secara khusus serta agar dapat memberikan perlindungan hukum terhadap pengguna fintech.

Berdasarkan uraian diatas maka dalam artikel ini yang hendak dibahas adalah: bagaimana Peraturan Hukum Yang di Keluarkan Bank Indonesia dan Otoritas Jasa Keuangan tentang

Doi.Org/10.1108/Ijlma-01-2018-0013

21 Rosenblum, R. H., Gault-Brown, S. A., \& Caiazza, A. B. (2015). Peer-to-peer lending platforms: Securities law considerations. Journal of Investment Compliance, 16(3), 15-18. Doi.Org/10.1108/Joic-06-2015-0038.

22 Koonprasert, T., \& Mohammad, A. G. (2020). Creating Enabling Fintech Ecosystems: The Role of Regulators. AfI Special Report, 2020-01.

23 Jagtiani, J., \& John, K. (2018). Fintech: The Impact on Consumers and Regulatory Responses. Journal of Economics and Business, 100, 1-6.

24 Miseviciute, J. (2018). Blockchain and Virtual Currency Regulation in the EU. Journal of Investment Compliance. 19(3), 33-38. DOI: .Org/10.1108/Joic-04-2018-0026.

25 Magnuson, W. (2018). Regulating fintech. Journal Vanderbilt Law Review, 71(4), 1167-1226.

26 Rosenblum, R. H., Gault-Brown, S. A., \& Caiazza, A. B. (2015). Peer-to-peer lending platforms: Securities law considerations. Journal of Investment Compliance, 16(3), 15-18. DOI: https://doi.org/10.1108/JOIC-06-20150038

27 Jagtiani, J., \& John, K. (2018). Fintech: the impact on consumers and regulatory responses. Journal of Economics and Business, 100, 1-6.

${ }^{28}$ Chatterjee, S. (2019). Op. Cit.

29 Carmona, A. F., Lombardo, A. G. Q., Pastor, R. R., Quirós, C. T., García, J. V., Muñoz, D. R., \& Martin, L. C. (2018). Competition issues in the area of financial technology (Fintech). Policy Department for Economic, Scientific and Quality of Life Policies of the European Parliament. Working Paper, Directorate General For Internal Policies Policy Department A: Economic And Scientific Policy, European Parliament

30 Barberis, J., Buckley, R., \& Arner, D. (2017). Fintech, Regtech, and the reconceptualization of financial regulation. Northwestern Journal of International Law \& Business, 37(3).

31 Saksonova, S., \& Kuzmina-Merlino, I. (2017). Fintech as Financial Innovation-The Possibilities and Problems of Implementation. European Research Studies Journal, 20(3), 961-973.

32 Treleaven, P. (2015). Financial Regulation of FinTech. Journal of Financial Perspectives, 3(3), 114-121 
fintech di Indonesia. Serta Urgensi Pembentukan UU fintech terhadap Perlindungan Konsumen fintech.

\section{B. METODE PENELITIAN}

Penelitian ini adalah penelitian hukum yuridis normatif, adapun yang dimaksud dengan penelitian yuridis normatif adalah penelitian hukum yang mendasarkan analisisnya pada perundang-undangan yang terkait dengan objek/masalah yang menjadi fokus penelitian. ${ }^{33}$ Data yang dipergunakan yaitu data kepustakaan yang diperoleh dari bahan hukum primer seperti undang-undang, POJK, PBI dan Bahan hukum sekunder seperti Buku-Buku hukum dan jurnal hukum. Data penelitian ini diperoleh dengan penelusuran pustaka. Selanjutnya dianalisis dengan menggunakan pendekatan deskriptif analilitis, yaitu cara menganalisis dengan mengambarkan objek yang diteliti.

\section{PEMBAHASAN}

\section{Peraturan Hukum Yang di Keluarkan Bank Indonesia dan Otoritas Jasa Keuangan tentang fintech di Indonesia}

Bank Indonesia (BI) dan Otoritas Jasa Keuangan, Masing-masing sudah mengeluarkan peraturan Hukum tentang pengaturan industry di Bidang fintech, dimana peraturan-peraturan tersebut dengan harapan memberikan keamanan bagi seluruh stakeholder terkait pengaturan fintech. peraturan-peraturan hukum yang di Keluarkan baik secara umum maupun secara khusus masih sangat terbatas, disisi lain ada juga peraturan-peraturan yang erat kaitanya dengan aktifitas transaksi di Industri fintech.

Secara umum, perkembangan fintech tidak hanya mempengaruhi hukum di Indonesia melainkan juga mempengaruhi system hukum di dunia, hal ini karena indutri fintech menjangkau batas-batas wilayah dengan berbasis teknologi yang mampu beroperasi melintasi batas yuridikasi. ${ }^{34}$ Berdasarkan fakta yang demikian Otoritas Jasa Keuangan (OJK) dan Bank Indonesia (BI) dalam upaya melindungi transaksi fintech sudah sedemikian gencarnya dengan mengeluarkan peraturan-peraturan terkait guna melindungi dan Mengatur tentang kegiatan dan transaksi di industri fintech sebagaimana peraturan hukum yakni POJK No. 77/POJK.01/2016 tentang Layanan Pinjam Meminjam Uang Berbasis teknologi Informasi. POJK Nomor. 13 tahun 2018 tentang Inovasi Keuangan Digital di Sektor Jasa Keuangan. POJK 37 tahun 2018 tentang Layanan Urun Dana melalui Penawaran Saham Berbasis teknologi Informasi. PBI Nomor 19 tahun 2017 tentang penyelenggaraan Teknologi Financial. PBI Nomor 20 tahun 2018 tentang Uang Elektronik.

Otoritas Jasa Keuangan sendiri dengan kewenangannya merumuskan kebijakan hukum dengan mengeluarkan POJK Nomor 77 tahun 2016 tentang Layanan Pinjam Meminjam Uang Berbasis teknologi Informasi. Pada Peraturan tersebut merupakan peraturan yang peratama kali di Keluarkan oleh Otoritas jasa Keuangan dalam melindungi permasalahan fintech secara langsung. Pada ketentuan Peraturan Otoritas Jasa Keuangan No. 77/POJK.01/2016 tentang Layanan Pinjam Meminjam Uang berbasis Teknologi Informasi layanan transaksi fintech merupakan sebuah jasa keuangan yang mengadalkan sarana teknologi dalam melakukan transaksi pinjam meminjam keuangan oleh para pihak terkait. Dengan peraturan Tersebut, maka system yang dibangun bukan lagi menggunakan layanan manual (konvesional), namun mengandalakan kemudahan teknologi yang memadai atau proses digitalisasi.

Peraturan hukum yang di ataur dalam ketentuan Peraturan Otoritas Jasa Keungan No. 77/POJK.01/2016 tersebut dalam hal sanksi. Pada ketentuan ini, sanksi atas pelanggaran yang

\footnotetext{
33 Soekanto, S. (2012), Pengantar Penelitian Hukum, Jakarta: Universitas Indonesia Press, h. 5

${ }^{34}$ Rahmayani, N. (2018). Tinjauan Hukum Perlindungan Konsumen Terkait Pengawasan Perusahaan Berbasis Financial Technology di Indonesia. Pagaruyuang Law Journal, 2(1), 24-41.
}

$$
\text { 538|S A S Vo1. } 27 \text { No.4, Oktober - Desember } 2021
$$


terjadi dalam transaksi fintech yang dalam pasal 47 ayat (1), menyebutkan bahwa atas pelanggaran kewajiban dan larangan dalam POJK ini, maka kewenangan OJK hanya mengenakan sanksi administrative terhadap Penyelenggara fintech berupa: (1) pringatan tertulis; (2) Denda, dengan kewajiban untuk membayar sejumlah uang tertentu; (3) pembatasan; dan, (4) pencabutan izin.

Sedangkan berdasarkan Pasal 47 ayat (2) peraturan OJK No. 77/POJK.01/2016 Layanan Pinjam Meminjam Uang berbasis Teknologi Informasi, menyebutkan bahwa "Sanksi administratif sebagaimana dimasksud dalam pada ayat (1) diatas terutama dalam huruf b sampai dengan huruf $d$, dapat dikenakan dengan atau tanpa didahuului pengenaan sanksi administrative berupa peringatan tertulis, sebagaimana dimaksud dalam pasal (1) huruf a.

Pada ketentuan lain sebagaimana terdapat pasal 47 ayat (3) Perturan OJK No. 77/POJK.01/2016 tentang Layanan Pinjam Meminjam Uang berbasis Teknologi Informasi hanya sebatas sanksi administratif saja. Dalam ketentuan pasal 1 ayat (3) ini tidak menyebutkan jumlah dana secara pasti yang harus di kenakan bagi pelaku yang melanggar. Dalam pasal-pasal diatas baik pasal 1 sampai dengan pasal 3 ini, tidak menyebutkan sanksi administratif maupun pidana bagi yang melakukan pelanggaran. Terutama pelanggaran yang dilakukan oleh industri fintech yang belum berijin atau yang illegal. Sedangkan sanksi hukum yang dapat diberikan kepada pelaku industri fintech yang berijin, pun demikian sanksi yang diberikan bagi fintech yyang berijin paling tinggi hanya sebatas pencabutan ijin terhadap perusahaan fintech yang melakukan pelanggaran.

Berdasarkan keterangan otoritas terkait sebagaimana yang ditangani oleh Satgas Waspeda Investasi selama 3 tahun terakhir mulai tahun 219 sampai dengan tahun 2021 ini. Terdapat kasus-kasus fintech-fintech illegal yang marak terjadi di berbagai media ddengan menawarkan produk-produk pinjaman. Pada tahun 2019 sendiri, kasus fintech Ilegal sebanyak 1,369 entitas fintech. ${ }^{35}$ dan tahun 2020, sebanyak 1120 fintech illegal, dan tahun tahun 2021 sebanyak 610 fintech illegal. ${ }^{36}$ Berdasarkan kondisi tersebut jika didasarkan pada Peraturan Otoritas Jasa keuangan No. 77/POJK.01/2016 tentang Layanan Pinjam Meminjam Uang berbasis Teknologi Informasi belum dapat menjadi landasan dalam penanganannya secara maksimal.

Dengan kondisi yang demikian, maka Peraturan Otoritas Jasa keuangan No. 77/POJK.01/2016 tentang Layanan Pinjam Meminjam Uang berbasis Teknologi Informasi masih sangat terbatas dalam menangani perkara-perkara yang timbul dalam transaksi fintech secara lebih luas. Padahal POJK No. 77/POJK.01/2016 tentang Layanan Pinjam Meminjam Uang berbasis Teknologi Informasi seharusnya dapai mengatasi berbagai masalah-masalah hukum yang muncul dari tranksaksi-transaksi pada industri fintech.

Dalam beberapa penelitian sebelumnya, sebagaimana yang dikemukana oleh Haryani, bahwa peran Otoritas Jasa keuangan di media internet seperti Tekfin dan Crowdfunding masih sangat lemah, oleh karenanya dalam pengaturan dan perlindungan hukum di Industri fintech masih terbatas karena kondisi regulasi yang masih kurang memadai, kondisi yang demikian maka dalam rencana revisi Undang-Undang OJK dimasa yang akan datang, OJK seharusnya diberi kewenangan yang sangat luas untuk mengatur dan mengawasi industri jasa keuangan seperti fintech. ${ }^{37}$

Otoritas Jasa Keuangan berdasarkan peraturan (POJK) No. 77/POJK.01/2016 tentang Layanan Pinjam Meminjam Uang berbasis Teknologi Informasi, diikuti juga dengan Surat Edaran atau SE OJK No. 18 /SEOJK.02/ 2017 tentang pelaksanaan Tata Kelola dan manajemen

35 Akbar, C. (2019). Lagi, OJK Temukan 297 Layanan Pinjaman Online Ilegal. Retrieved from https://bisnis.tempo.co/read/1266896/lagi-ojk-temukan-297-layanan-pinjaman-online-ilegal

36 Data Fintech illegal, Berdasarkan Rilisan Otoritas Jasa Keuangan Per 4 Mei 2021. https://www.ojk.go.id/id/Default.aspx Di Akses Pada tanggal 24 Juni 2021

37 Hariyani, I. (2018). Perlindungan Hukum dan Penyelesaian Sengketa Bisnis Jasa PM-Tekfin. Jurnal Legislasi Indonesia, 14(3), 345-358.

$$
\text { 539|SASI Vol. } 27 \text { No.4, Oktober - Desember } 2021
$$


Risiko Teknologi Informasi pada Layanan Pinjam Meminjam Uang berbasis teknologi Informasi. Bahwa dalam peraturan atau Surat Edaran tersebut hanya sebagai upaya tata kelola dan menyikapi terkait manajemen risiko yang timbul dari transaksi fintech.pada beberapa isi pasalnya juga belum membahas terkait penyelesaian sengkketa yang timbul akibat tranksaksi di fintech, baik fintech yang berijin ataupun fintech yang belum berijin (illegal). Dengan demikian peraturan yang dibuat oleh OJK tentang transaksi fintech selama ini belum dapat menyelesaikan serta memberikan perlindungan hukum secara kuat bagi pelaku pelanggaran fintech di Indonesia.

Disampin itu, OJK juga mengeluarkan POJK Nomor 13/POJK.02/2018 tentang Inovasi Keuangan Digital di sector Jasa Keuangan. Pada peraturan ini sendiri OJK mengatur berbagai jenis fintech yang didalamnya mengatur berbagai jenis-jenis fintech baik cara pendaftaran, bentuk badan hukum, catatan penyelenggaraan, regulatori sandbox, pendaftaran penyeleggara Inovasi Keuangan Digital, pemantauan, pelaporan, tata kelola, perlindungan dan kerasiahan data, serta edukasi dan perlindungan konsumen. Pada peraturan-perturan ini pada kesimpulanya mengatur tata kelola dan administrasi pelaporan industri fintech, sehingga pada aspek perlindungan hukum terhadap konsumen fintech masih belum memadai.

Selanjutnya adalah POJK Nomor 37/POJK.03/2018 tentang Layanan Urun Dana melalui ppenawaran saham berbasis teknologi Informasi. Pada peraturan ini Otoritas Jasa Keuangan hanya mengatur pembiayaan alternatif untuk dunia usaha (bisnis) baik melalui mpendanaan langsng, pendanaan berbasis teknologi, atau pendanaan berbasis ekuitas, serta didalamnya hanya mengatur perijinan penyelenggaraan, kegiatan usaha, bentuuk badan hukum dan pemodalan, kewajiban dan larangan, layanan crowdfunding, penggunaan crowdfunding, perjanjian layanan crowdfunding, mitigasi resiko, tata kelola, system tekonologi informasi untuk menyediakan layanan crowdfunding, edukasi dan perlindungan tanda tangan elektronik.

Berdasarkan ketentuan-ketentuan tersebut OJK melalui peraturan yang dikeluarkannya Baik POJK maupun SEOJK hanya mengatur secara administratif, baik berupa syarat fintech itu harus berbentuk hukum, Jenis fintech serta tata kelola dalam industri fintech. sewalaupun dalam beberapa aturan tersebut menyebutkan perlindungan hukum dan sangksi hukum bagi pelaku fintech, tetapi pada aspek yuridisnya upaya perlindungan hukum yang diberikan berupa ganti rugi sebagian tanpa disebutkan jumlah minimal, serta sanksi administratif yang diberikan bagi pelanggar adalah sangsi masksimum pencabutan izin. Dengan demikian bahwa dalam perlindungan konsumen di industri fintech, peraturan perlindungan konsumen dalam tarnsaksi fintech hanya didasarkan pada beberapa peraturan yang dikeluarkan oleh BI dan OJK dan Kemeninfo dan masih kurang memadai.

Disamping Otoritas Jasa Keuangan yang mempunyai kewajiban dalam mengawasi dan mengontrol industri fintech di Indonesia. Bank Indonesia (BI) Juga merupakan lembaga Negara independen yang berwenang mengatur dan menjaga kelancaran system pembayaran nasional. Dengan demikian Bank Indonesia mendorong perkembangan industri fintech guna merespon teknologi informasi dan komunikasi serta perkembangan bisnis digital. Dengan demikian perkembangan bisnis di industrii fintech diharapkan dapat memperluas partisipasi masyarakat dalam ndustri jasa keuangan. ${ }^{38}$

Sebagaimana yang disebutkan di atas Bank Indonesia telah menerbitkan Peraturan BI No. 18/ 40/ PBI/2016 tenteng Penyelenggaraan Pemrosesan Transaksi Pembeyaran sebagai payung hukum bagi pengembangan bisnis fintech di Indonesia. Perlindungan hukum bagi nasabah dan pelaku industri fintech di Indonesia. Dalam perlindungan hukum bagi nasabah dan pelaku usaha fintech di ataur dala undang-undang Informasi dan Trnsaksi Elektronik (UU-ITE), Undang Undang perlindungan Konsumen, Peraturan Pemerintah No. 22 tahun 2012 tentang

\footnotetext{
38 Basrowi, B. (2019). Analisis Aspek Dan Upaya Perlindungan Konsumen Fintech Syariah. Lex Librum: Jurnal Ilmu Hukum, 5(2), 959-980.
} 
penyelenggaraan Sistem dan Transaksi Elektronik, Peraturan BI No. 16/1/PBI/2014 tentang perlindungan Konsumen Penyelenggara Sistem Pembayaran, dan Peraturan BI Nomor. 18/40/ PBI / 2016 tentang Penyelenggaraa Pemrosesan Transaksi Pembayaran Pelaku Usaha yang ingin menjadi penyedia Jasa Sistem pembayaran atau (PJSP) untuk pertama kali, harus mendapat ijin dari Bank Indonesia. ${ }^{39}$

Disamping perturan tersebut ada juga peraturan Bank Indonesia Nomor. 9 tahun 2017 tentang Penyelenggaraan teknologi Financial. Pada peraturan BI ini, kewenangan Bank Indonesia hanya mengatur pelaksanaan fintech khususnya dalam hal penyediaan layanan system pembayaran, yang didalamnya mengenal prinsip kehati-hatian, diantaranya kenali pelanggan anda, prinsip regiistrasi, regulatori sandbox, perijinan penyelenggara pemantauan dan pengawasan kerjasama penyelenggara antara penyelenggara jasa system pembayaran dan penyelenggara teknologi keunangan. Serta mengatur koordinasi dan kerjasama Bank Indonesia dengan Otoritas terkait baik dalam negeri maupun di luar negeri. Dengan demikian secara yuridis berdasarkan paparan diatas bahwa kewenangan Bank Indonesia tidak mempunyai kewenangan langsung terhadap upaya perlindungan hukum terhadap kegiatan industri fintech di Indonesia. Peraturan hukum yang mengatur kegiatan dalam industri fintech yang bersifat online dan menggunakan transaksi elektronik masih belum memadai.

Kalau merujuk undang-undang No. 8 tahun 1999 tentang perlindungn Konsumen secara umum, bahwa konsumen yang membeli produk/barang atu jasa dengan melakukan transaksi pembayaran via internet harus mendapatkan perlindungan hukum agar mereka tidak dirugikan oleh pelaku usaha. Ketentuan-ketentuan ini hanya sebatas mengatur konsumen secara umum tidak secara spesifikasi mengatur konsumen dalam industri fintech. sedangkan masyarakat dalam melakukan kegiatan di indstri fintech harus dilindungi dari praktek penipuan dan kejahatan-kejahat lainnya terutama dalam kegiatan bisnis online dan transaksi elektronik. Otoritas terkait sebagaimana OJK harus sangat memperhatikan aspek-aspek hukum dalam perlindungan hukum terhadap konsumen. Sewalaupun dalam beberapa kebijakan hukum yang dikeluarkan oleh Otoritas Jasa Keuangan sebagaimana Peraturan OJK No. 1/POJK.07/ 2013 tentang Perlindungan Konsumen Sektor Jasa Keuangan serta Surat Edaran Otoritas Jasa Keungan No. 2/SEOJK.07/2014 tentang Pelayanan dan Penyelesaian Pengaduan Konsumen pada pelaku Usaha Jasa Keuangan ${ }^{40}$. Masih belum memadai dan sansksi hukumnya masih bersifat administratif, oleh karena nya upaya penegakan hukum serta perlindungan hukum terhadap konsumen tidak dapat diterapkan secara maksimal.

Kegiatan dalam industri fintech baik secara ofline maupun secara online harusnya menerapkan prinsip-prisnsip hukum perlindungan konsumen dan menerapkan asas itikad baik kepada konsumen dalam melakukan kegiatan usahanya. ${ }^{41}$ Merujuk Undang-undang No. 8 tahun 1999 pasal 4 tentang Perlindungan Konsumen, didalamnya sangat menjunjung tinggi perlindungan hukum terhadap konsumen baik dalam kegiatan barang/jasa, hal ini sebagaimana disebutkan tentang hak-hak konsumen yang harus dipenuhi antara lain: (1) Ha katas kenyamanan, keamanan, dan keselamatan dalam mengkonsumsi barang dan/atau jasa; (2) hak untutk memilih barang/jasa serta mendapatkan barang dan/atau jasa tersebut sesuai dengan nilai tukar dan kondisi serta jaminan yang dijanjikann; (3) ha katas informasi yang benar, jelas, dan jujur mengenai kondisi dan jaminan barang dan/atau jasa; (4) hak untuk di dengar pendapat dan keluhan atas barang atau/jasa yang digunakan; (5) hak untuk mendapatkan adfokasi, perlindungan dan upaya penyelesaian sengketa perlidnungan konsumen secara patut; (6) hak untuk diperlakukan atau dilayani secara benar dan jujur serta tidak diskriminatif; (7) hak untuk mendapatkan kompensasi, ganti rugi dan /atau penggantian, apabila barang dan /atau jasa yang diterima tidak sesuai dengan perjanjian atau tidak sebagaimana mestinya. (8) Hak untuk

39 Ibid.

40 Hariyani, I. (2018).. Op. Cit.

41 Benuf, K., Mahmudah, S., \& Priyono, E. A. (2019). Perlindungan Hukum Terhadap Keamanan Data Konsumen Financial Technology Di Indonesia. Refleksi Hukum: Jurnal Ilmu Hukum, 3(2), 145-160.

$$
\text { 541|S A S Vo1. } 27 \text { No.4, Oktober - Desember } 2021
$$


mendapatkan pembinaan dan penddikan konsumen; (9) dan, hak-hak yang diatur dalam ketentuan peraturann perundang-undangann lainnya.

Berdasarkan paparan diatas, menurut Bagus handiyo Mantri sebagaimana dikutip oleh Haryani dalam jurnalnya, bahwa Undang-undang perlindungan Konsumen No. 8 tahun 1999 tentang Perlindungan Konsumen, belum dapat melindungi konsumen dalam kegiatan transaksi e-commerce karena keterbatasan pengertiann pelaku usaha yang hanya khusus berada di wilayah Negara kesatuan Republik Indonesia, dan keterbatasan hak-hak yang diatur dalam UU Perlindungan Konsumen. ${ }^{42}$

Perlindungan hukum terhadap konsumen yang seharusnya diatur meliputi perlindungan hukum dari sisi pelaku usaha, perlindungan hukum dari sisi konsumen, perlindungan hukum dari sisi produk yang ditawarkan dan perlindungan hukum dari sisi transaksi. Permasalah yang timbul sebagai akibat kekosongan hukum ini adalah mencakup semua dalam aspek yuridis maupun non yuridis baik meliputi keabsahan menurut Kitab Undang Hukum Perrdata, Penyelesaian sengketa hukum transaksi e-commerce, Undang-Undang Perlindungan Konsumen yang tidak akomodatif, dan seterusnya. Sedangkan permalasahan lain yang secara non yuridis yang meliputi keamanan tarnsaksi, penyebaran data pribadi, pengacaman, terror, bunga tinggi serta tidak pahamnya masyarakat konsumen dalam melakukan transaksi di e-commerce atau dalam industri fintech.

Sedangkan dalam peraturan lainya yang mengatur hal yang serupa sebagaimana terdapat dalam Undang-undang Nomor. 11 tahun 2008 tentang Informasi dan Transaksi Elektronik, bahwa perlindungan konsumen dibidang transaksi elektronik terkait transaksi fintech juga dapat didasarkan pada Pasal 13 ayat 2 Undang-udang ITE yang menyebutkan bahwa "para pihak yang melakukan transaksi elektronik, sebagaimana dimaksud pada ayat 1 wajib beritikad baik dalam melakukan interaksi dan/atau pertukaran informasi eleketronik dan/atau dokumen elektronik selama transaksi berlangsung. Sedangkan pasal $45 \mathrm{~s} / \mathrm{d}$ pasal 52 Undang-undang No. 11 Tahun 2008 tentang ITE secara jelas menyatakan tentang ketentuan pidana bagi para pelanggar perjanjian transaksi elektronik. Sedangkan merujuk Pasal 53 menyatakan bahwa, pada saat berlakunya undang-undang ini, semua peratuuran perundnag-undangan dan kelembagaan yang berhubungan dengan pemanfaatan teknologi informasi yang tidak bertentangan dengan undang-undang ini dinyatakan tetap berlaku.

Berdasarkan paparan peraturan perundang-undangan dalam transaksi di Industri fintech diatas masih bersifat umum. Sedangkan secara khusus perundang-perundangan yang mengatur tentang penyelewengan terhadap transaksi di industri fintech khususnya fintech yang illegal belum ada. Dengan kondisi yang demikian maka otoritas terkait harus merespon dengan bijak agar merumuskan satu kebiijakan hukum dalam pembentukan UU fintech baik dalam kondisi pandemic covid-19 maupun sesudah pandemic covid-19, agar peraturan-peraturan tersebut dapat menyokongnya terkait transaksi fintech di Indonesia guna melindungi para pihak dalam transaksi fintech.

Disamping secara yuridis sebagaiman terdapat dalam uraian pada peraturan perundangundangan diatas, dapat juga beberapa alasan secara non yuridis sebagai landasan hukum pentingnya pembentukan undang-Undang fintech di Indonesia, apalagi dalam kondisi pandemic covid-19 ini antara lain:

Pertama, kondisi pertumbuhan ekonomi Indonesia yang pesat dan potensi dan potensi industry fintech di Indonesia yang sangat besar perlu didukung oleh kerangka hukum yang kuat dan kemprehensif. Kondisi ini, mengingat Indonesia merupakan penduduk terbesar keempat dunia setelah China, Amerika Serikat dan India, serta pertimbangn bahwa Negara tersebut masuk dalam nominasi ekonomi tersbesar ke 16 dunia, UU fintech akan memberikan kepastian hukum bagi industry secara keseluruhan dan menjadi dasar perlindungan hukum bagi pengguna

${ }^{42}$ Hariyani, I. (2018).. Op. Cit.

542|SASI Vo1. 27 No.4, Oktober - Desember 2021 
jasa Fintech, investor dan pelaku sekaligus menyelesaikan kekosongan hukum yang ada.

Kedua, pada tahun 2019 yang lalu banyaknya praktek Fintech illegal kondisi ini atas dasar tidak memadainya regulasi yang ada sehingga mengakibatkan kondisi perlindungan hukum yang tidak maksimal. Satgas waspada investasi melaporkan terdapat 2.018 Peer To Peer Lending illegal, 472 perusahaan investasi illegal dan 69 pegadaian illegal. ${ }^{43}$ Hal ini menunjukan bahwa tidak adanya Undang-Undang Fintech, dan membuka peluang terhadap pelanggaran hukum dalam industry fintech. sedangkan peraturan yang berlaku sekarang baik Peraturan OJK maupun Peraturan BI memiliki legal standing yang rendah dan tidak memuat ketentuan pidana.

Ketiga, undang-undang Fintech akan berfungsi sebagai sarana mitigasi risiko dalam ekosistem ekonomi digital. ${ }^{44}$ Hal ini dilakukan sebagai sarana literasi keuangan, Pengawasan, perlindungan konsumen serta pemberian izin pada aktifitas Fintech. sebagai akibatnya adalah akan menciptakan system keuangan yang stabil dan mempercepat ekonomi digital. ${ }^{45}$ Disamping itu upaya penguatan Otoritas terkait sangat penting dilakukan dan harus diatur dalam UU Fintech, terutama mengenai pencegahan resiko sistemik dan pengelolaan krisis keuangan untuk mewujudkan perekonomian nasional yang berkelanjutan. Untuk mencapai tujuan ekonomi digital yang stabil dan berkelanjutan, instansi dan otoritas terkait perlu memiliki peran yang jelas dalam melakukan pengawasan kegiatan fintech.

Berdasarkan kondisi yang dipaparkan diatas baik secara yuridis maupun non yuridis, Indonesia membutuhkan landasan hukum yang memadai, dengan alternatif nya adalah Pembentukan Undang-Undang Khusus fintech sebagai langkah yang tepat dalam merespon perkembangan ekonomi digital yang menuntut kerangka hukum yang komperehensif dan berfungi sebagai strategis dalam perlindungan konsumen, pencegahan dalam praktek illegal, dan upaya mitigasi risiko sistemik di industry jasa keungan digital di Indonesia.

\section{Urgensi Pembentukan UU fintech terhadap Perlindungan Konsumen fintech}

Konstitusi Indonesia bertujuan mewujudkan perlindungan hukum terhadap hak setiap anggota masyarakat diseluruh Negara kesatuan. Konstitusi bagi bangsa Indonesia adalah kesepakatan, yang harus ditaati, dan dilaksanakan. ${ }^{46}$ Hal ini telah menjadi ciri bangsa Indonesia yang mengedepankan demokrasi dalam setiap pengambilan keputusan yang berkaitan dengan kepentigan nasional bangsa. Perjalanan demokrasi di Indonesia tidak berjalan mulus, banyak fase yang sudah dilewati, fase terakhir yaitu reformasi. Cita-cita reformasi yang berkaitan langsung dengan tujuan bangsa Indonesia adalah menjamin kelancaran produktivitas warga masyarakat dan kehidupan ekonomi yang mensejahterahkan rakyat Indonesia. ${ }^{47}$. Dengan demikian kesejahteraan masyarakat adalah kunci dalam penyelenggaraan Negara Kesatuan Indonesia.

Banyaknya ancaman dan pembobolan atau pencurian data konsumen diluar dari kelengahan perusahaan, yang bisa mengakibatkan kurang baiknya system perlidungan data privasi yang diterapkan oleh pelaku usaha dalam industry fintech ataupun bahaya dari adanya tindakan dari pelaku bisnis yang secara sengaja mengambil data konsumen dapat menyebabkan instabilitas dalam perkembangan industry fintech di Indonesia. Ancaman terhadap data data pribadi konsumen juga dapat dilakukan oleh pelaku-pelaku atau pekerja pada perusahaan fintech yang memiliki niat untuk mengambil data digital pengguna untuk memenuhi kebutuhan

43 Santoso, W. (2020, March). Fintech and the future of finance. In International Seminar on Fintech and The Future of Finance (Vol. 12).

44 Ehrentraud, J., Ocampo, G. D., Garzoni, L., \& Piccolo, M. (2020). Policy responses to fintech: a cross-country overview, BIS, Financial Stability Institute. Insight on policy implementation, (23).

45 Benuf, K., Mahmudah, S., \& Priyono, E. A. (2019). Op. Cit.

46 Mitendra, H. M. (2018). Fenomena dalam Kekosongan Hukum. Jurnal Rechtsvinding, 1.

47 Nursamsi, D. (2014). Kerangka Cita Hukum (Recht Idee) Bangsa Sebagai Dasar Kewenangan Mahkamah Konstitusi Menguji Peraturan Pemerintah Pengganti Undang-Undang (Perppu). Jurnal Cita Hukum, 2(1).

$$
\text { 543|SASI Vol. } 27 \text { No.4, Oktober - Desember } 2021
$$


dan kepentingannya. Kondisi ini dapat membuat industry fintech yang telah berkembang pesat di Indonesia memperoleh label yang rendah dari Negara lain yang sudah lebih dulu membuat peraturan perlindungan hukum terhadap data-data serta ancaman terhadap industry fintech.

Hadirnya hukum adalah merupakan respon terhadap kebutuhan masyarakat sebagaimana yang disebutkan diatas, gagasan serta kebijakan yang tepat dapat meberikan perlindungan hukum yang tepat pula bagi para pelaku industry fintech. hukum hadir sebagai respon terhadap gejala atau venomena-venomena sosial terhadap kebutuhan masyarakat yang dinamis dan permasalahan masyarakat. Permasalahan yang dihadapi masyarakat juga semakin hari semakin berkembang, ${ }^{48}$ dengan demikian maka tujuan hukum adalah memberikan perlindungan (Pengayoman) kepada masyarakat. ${ }^{49}$ Perlindungan hukum adalah perlindungan terhadap harkat dan martabat serta pengakuan terhadap Hak Asasi Manusia yang dimiliki oleh subjek hukum yang didasarkan pada hukum positif, jadi bisa disimpulkan perlindungan hukum berfungsi melindungi kepentingan manusia. ${ }^{50}$ Kepentingan masyarakat Indonesia sangat beragam, hal ini dikarenakan masyarakat Indonesia yang heterogen dan memiliki kebudayaan serta kebiasaan yang berbeda-beda. ${ }^{51}$ Namun dengan adanya penyebaran Covid- 19 di Indonesia, kepentingan masyarakat menjadi satu yaitu kepentingan akan perlindungan hukum bagi keselamatan seluruh masyarakat Indonesia. Perlindungan hukum merupakan pemberian Keadilan, Kepastian dan Kemanfaatan bagi seluruh anggota masyarakat, yang diwujudkan dalam kebijakan nasional. ${ }^{52}$ Kebijakan nasional diwujudkan dalam suatu peraturan perundangundangan yang bisa mengakomodir seluruh kepentingan masyarakat Indonesia. ${ }^{53}$ Perlindungan Kepada masyarakat prinsipnya sama dengan perlindungan konsumen. Karena seluruh masyarakat Indonesia adalah konsumen, sehingga kepentingan atas suatu pelrindungan hukum bagi konsumen merupakan kepentingan dari seluruh penduduk Indonesia. ${ }^{54}$ Perlindungan konsumen bertujuan untuk memberikan jaminan kepastian hukum untuk kensumen yang mengalami kerugian. ${ }^{55}$ Kondisi penyebaran covid-19 saat ini hanya sebagai pemicu awal terhadap perkembangan industry fintech, yang pada sesungguhnyaregulasi khusus fintech sangat dibutuhkan, kondisi ini bukan saja dibutuhkan pada pandemic covid-19, melainkan juga pada kebutuhan yang akan datang, dengan adanya suatu regulasi dan/atau kebijakan hukum terhadap industri fintech maka seluruh masyarakat dapat terlindungan aktifitasnya dalam kegiatan fintech.

Sesungguhnya, Perlindungan hukum terhadap masyarakat yang terdampak pandemic covid -19 sebagai bentuk dasar pembangunan bangsa dengan mewujudkan keadilan sosial bagi seluruh rakyat Indonesia, sebab keadilan sosial hanya akan terwujud bilamana seluruh masyarakat Indonesia berdampak Covid-19 merasakan perlindungan hukum yang sama. ${ }^{56}$ Keadaan masyarakat Indonesia ditengah penyebaran pandemic covid-19 membuat masyarakat kesulitan untuk bekerja, sehingga masyarakat tidak mendapatkan penghasilan di tengah kondisi pandemic covid-19.

Gagasan serta kebijakan hukum terhadap pembentukan Undang-undang Fintech,

48 Raharjo, S. (2017). Membedah Hukum Progresif, Jakarta: Penerbit Kompas, Cetakan ke 2. h. 267

49 Ibid.

50 Musyafah, A. A. (2019). Peran Otoritas Jasa Keuangan (OJK) Dalam Hal Perlindungan Nasabah Pada Lembaga Keuangan Mikro Syariah. Law, Development and Justice Review, 2(2), 194-211.

51 Badriyah, S. M. (2011). Penemuan Hukum (Rechtsvinding) dan Penciptaan Hukum (Rechtsschepping) oleh Hakim untuk Mewujudkan Keadilan. Masalah-Masalah Hukum, 40(3), 384-392.

52 Hartini, S., Sudrajat, T., \& Bintoro, R. (2012). Model Perlindungan Hukum terhadap Kebijakan Pelayanan Kesehatan Masyarakat Miskin di Kabupaten Banyumas. Jurnal Dinamika Hukum, 12(3), 523-534.

53 Benuf, K. (2018). Politik Hukum Legislator dan Ideologi Pancasila. Gema Keadilan, 5(1), 85-92.

54 Nasution, A. (2017). Sekilas Hukum Perlindungan Konsumen. Jurnal Hukum \& Pembangunan, 16(6), 568-581.

55 Syafriana, R. (2017). Perlindungan konsumen dalam transaksi elektronik. De Lega Lata: Jurnal Ilmu Hukum, 1(2), 430-447.

56 Benuf, K. (2020). Urgensi Kebijakan Perlindungan Hukum terhadap Konsumen Fintech Peer To Peer Lending Akibat Penyebaran COVID-19. Jurnal Rechts Vinding: Media Pembinaan Hukum Nasional, 9(2), 203. 
bertujuan untuk merancang kerangka kebijakan dan mendorong serta mendukung inovasi untuk meningkatkan inklusi keuangan dan pertumbuhan ekonomi sekaligus memberikan perlindungan hukum terhadap keamanan dan kesehatan system perbankan dan stabilitas keuangan secara keseluruhan, ${ }^{57}$ dalam merancang regulasi fintech, para regulator berusaha memberikan aturan yang jelas, serta menjaga integritas pasar, dan mendorong inovasi fintech. ${ }^{58}$ Bahaya yang timbul sebagai akibat tidak adanya aturan hukum dalam perlindungan industry fintechdapat berdampak buruk terhadap konsumen, dan dapat merugikan konsumen baik secara moril maupun materil, hal ini akibat banyaknya ancaman atau pencurian data para konsumen yang dilakuka oleh para pelaku industri fintech illegal.

Berdasarkan kondisi yang demikian maka dalam kebijakan pembentukan UndangUndang Fintech paling tidak memuat sanksi hukum yang cukup memadai dalam memberikan sangsi terhadap para pelaku yang nakal. Harapan nya dalam peraturan perundang-undangan Fintech dimuat Kerangka hukum fintech sebagai upaya strategis untuk memperkuat langkah hukum perlindungan konsumen digital di Indonesia diantarnya yaitu: Pertama, pada aspek Pengaturannya, Jenis layanan, Legalitas fintech serta kegiatan bisnis bisnis fintech, nantinya harus secara eksplisit memaparkan jenis layanan fintech dan kegiatan bisnis yang legal di Indonesia.

Kedua, Otoritas Pengawasan dan Regulator di Industri financial. Pada ketentuan ini penting dilakukan karena mengingat jenis -jenis fintech yang ada di Indonesia tidak hanya diawasi oleh OJK tetapi juga diawasi oleh Bank Indonesia. ${ }^{59}$ serta Pembagian peran dan kewenangan kedua institusi yang jelas diperlukan dan dipetakan untuk menghindari tumpah tindih dan untuk memastikan bahwa mereka dapat berkoordinasi secara konperehensif dalam upaya menjaga stabilitas keuagan. ${ }^{60}$ Selain itu, peran kementrian Keuangan juga harus diatur disini, karena kementrian keuangan memiliki kewenangan fiscal dan mewakili pemerintah. Hal penting lainnya adalah koordinasi dan kolaborasi otoritas sector jasa keuangan dengan regulator merupakan parameter dibidang lain seperti perlindungan data dan risiko siber. ${ }^{61}$

Ketiga, Kewajiban dan Larangan bagi penyelenggara layanan financial technology. Pada dasar Muatannya, Bagian Ini Harus Mengatur Tentang Penyedia Layanan Fintech, Tentang Pengaturan Mana Yang Wajib dilakukan dan tidak boleh dilakukan. Paling Tidak memuat subjek Pelaporan, Pengawasa Independen dan hal lainnya. ${ }^{62}$

Keempat, Perlindungan Konsumen, Muatanya, Bagian ini harus memuat ketentuan tentang tanggungjawab penyelenggara fintech dalam melindungi data para pengguna jasa fintech, dengan menyediakan system cyber yang dapat menjamin kerahasian data konsumen.

Kelima, Education konsumen, Muatanya, Bagian ini adalah upaya pendidikan konsumen yang dilakukan oleh Otoritas dan penyelenggara fintech untuk memberikan edukasi bagi para masyarakat pengguna jasa fintech, dengan cara memberdayakan Konsumen, menginformasikan model layanan fintech, resiko, peringatan saat menggunakan produk fintech. dst. Serta mendorong partisipasi aktif semua yang berkepentingan guna meningkatkan literasi dan inklusi keuangan.

Keenam, Sanksi Pidana, Bagian ini mengatur tentang sanksi yang diberikan kepada penyelenggara fintech yang melakukan pelanggaran dalam hal gagal melaksanakan

${ }^{57}$ Brummer, C., \& Yadav, Y. (2018). Fintech and the Innovation Trilemma. Georgetown Law Journal, 107(2), 235-307.

58 Ibid

${ }_{59}$ Widijantoro, J. (2019). The Role of Financial Services Authority in The Consumer Protection Amid The Growth of Fintech Industry in Indonesia. Mimbar Hukum-Fakultas Hukum Universitas Gadjah Mada, 31(2), 297-308.

${ }^{60}$ Ehrentraud, J., Ocampo, G. D., Garzoni, L., \& Piccolo, M. (2020). Op. Cit.

${ }^{61}$ Batunanggar, S. (2019). Op. Cit.

${ }^{62}$ Ringe, W. G., \& Christopher, R. U. O. F. (2020). Regulating Fintech in the EU: the Case for a Guided Sandbox. European Journal of Risk Regulation, 11(3), 604-629. 
kewajibannya. Serta pada bagian ini juga harus mengatur sangsi yang diberikan kepada pemilik kegiatan yang melakukan praktik illegal.

Adanya kebijakan pembentukan undang-undang khusus fintech adalah untuk mengatur secara lengkap terhadap perkembangan industri fintech dan diharapkan dapat memanimalisir dan mengatasi penyelewengan yang terjadi dilapangan. Dengan demikian industri fintech di Indonesia dapat secara maksimal bagi kemudahan layanan keuangan pada industry 4.0 ini. dengan undang-undang yang lengkap dapat mejadi kekuatan hukum dan juga merupakan tanggungjawab bagi penegak hukum yaitu kepolisian bukan saja dinitiberatkan pada Otoritas Jasa Keuangan, dengan demikian maka dalam menjalankan rambu-rambu yang berlaku dimasyarakat dapat teruwujud ekosistem dan tata kehidupan masyarakat menjadi tertib.

\section{P E N U T U P}

Berdasarkan hasil dan pembahasan sebagaimana dipaparkan diatas ditemukan bahwa selama ini fintech di Indonesia menggunakan regulasi yang berada didalam POJK dan PBI sebagai dasar pemberlakuan fintech, meskipun dirasa regulasi yang di keluarkan Oleh POJK dan PBI ini belum dapat memberikan perlindungan hukum yang maksimal terhadap pelaksanaan industri fintech. sehingga perlu kiranya pembentukan Undang-undang khusus dan atau formulasi hukum yang tepat dalam mengatur industri fintech di Indonesia. Peran OJK sebagai lembaga yang berwenang dan bertanggungjawab terhadap industri fintech, masih sangat terbatas dalam mengatasi permasalah hukum yang timbul. Kondisi ini disebabkan karena peraturan -peraturan yang berlaku sekarang masih sangat terbatas dan perlu adanya peraturan yang lebih tinggi (seperi UU), sebagaimana UU yang berlaku disektor jasa keuangan lainnya. Dengan demikian kehadiran peraturan perundang-undangan fintech yang secara khusus, menyeluruh dan lebih tinggi sangat urgen untuk dibentuk sebagai upaya perlindungan hukum disektor industri fintech Indonesia. Tujuan dari pembentukan undang-undang khusus fintech agar memberikan implikasi positif, agar pemerintah dengan segera membentuk Undang-undang khusus fintech. sehingga peraturan hukum yang dibentuk tersebut dapat memberikan keamanan dalam kegiatan transaksi fintech di Indonesia.

\section{DAFTAR PUSTAKA}

\section{Jurnal}

[1] Allen, F., Gu, X., \& Jagtiani, J. (2020). A Survey of Fintech Research and Policy Discussion. Doi.org/10.21799/frbp.wp.2020.21.

[2] Badriyah, S. M. (2011). Penemuan Hukum (Rechtsvinding) dan Penciptaan Hukum (Rechtsschepping) oleh Hakim untuk Mewujudkan Keadilan. Masalah-Masalah Hukum, 40(3), 384-392.

[3] Barberis, J., Buckley, R., \& Arner, D. (2017). Fintech, Regtech, and the reconceptualization of financial regulation. Northwestern Journal of International Law \& Business, 37(3).

[4] Basrowi, B. (2019). Analisis Aspek Dan Upaya Perlindungan Konsumen Fintech Syariah. Lex Librum: Jurnal Ilmu Hukum, 5(2), 959-980.

[5] Benuf, K. (2018). Politik Hukum Legislator dan Ideologi Pancasila. Gema Keadilan, 5(1), $85-92$.

[6] Benuf, K., Mahmudah, S., \& Priyono, E. A. (2019). Perlindungan Hukum Terhadap Keamanan Data Konsumen Financial Technology Di Indonesia. Refleksi Hukum: Jurnal Ilmu Hukum, 3(2), 145-160.

[7] Benuf, K. (2020). Urgensi Kebijakan Perlindungan Hukum terhadap Konsumen Fintech Peer To Peer Lending Akibat Penyebaran COVID-19. Jurnal Rechts Vinding: Media Pembinaan Hukum Nasional, 9(2), 203.

[8] Batunanggar, S. (2019). Fintech Development and Regulatory Frameworks in Indonesia. Asian Development Bank Institute, 1014(1014), 1-12.

$$
\text { 546|SASI Vo1. } 27 \text { No.4, Oktober - Desember } 2021
$$


[9] Benuf, K., Mahmudah, S., \& Priyono, E. A. (2019). Perlindungan Hukum Terhadap Keamanan Data Konsumen Financial Technology Di Indonesia. Refleksi Hukum: Jurnal Ilmu Hukum, 3(2), 145-160.

[10] Brummer, C., \& Yadav, Y. (2018). Fintech and the Innovation Trilemma. Georgetown Law Journal, 107(2), 235-307.

[11]Chatterjee, S. (2019). Is data privacy a fundamental right in India? An analysis and recommendations from policy and legal perspective. International Journal of Law and Management, 61(1), 170-190. Doi.Org/10.1108/Ijlma-01-2018-0013.

[12]Claessens, S., Frost, J., Turner, G., \& Zhu, F. (2018). Fintech credit markets around the world: size, drivers and policy issues. BIS Quarterly Review September.

[13] Hairi, P. J. (2020). Implikasi Hukum Pembatasan Sosial Berskala Besar Terkait Pencegahan COVID-19. Info Singkat Bidang Hukum, 12 (April), 1-6.

[14]Hariyani, I. (2018). Perlindungan Hukum dan Penyelesaian Sengketa Bisnis Jasa PMTekfin. Jurnal Legislasi Indonesia, 14(3), 345-358.

[15]Hartini, S., Sudrajat, T., \& Bintoro, R. (2012). Model Perlindungan Hukum terhadap Kebijakan Pelayanan Kesehatan Masyarakat Miskin di Kabupaten Banyumas. Jurnal Dinamika Hukum, 12(3), 523-534.

[16] Jagtiani, J., \& John, K. (2018). Fintech: The Impact on Consumers and Regulatory Responses. Journal of Economics and Business, 100, 1-6.

[17] Johnson, P. S., \& Harefa, A. A. (2018). Financial Technology, Regulation and Banking Adaptation in Indonesia. Fundamental Management Journal, 3 (1), 1-11.

[18] Kunarso, K., \& Sumaryanto, A. D. (2020). Eksistensi Perjanjian Ditengah Pandemi Covid19. Batulis Civil Law Review, 1(1), 33-46.

[19] Magnuson, W. (2018). Regulating fintech. Journal Vanderbilt Law Review, 71(4), 11671226.

[20] Mitendra, H. M. (2018). Fenomena dalam Kekosongan Hukum. Jurnal Rechtsvinding, 1.

[21] Miseviciute, J. (2018). Blockchain and Virtual Currency Regulation in the EU. Journal of Investment Compliance. 19(3), 33-38. DOI: .Org/10.1108/Joic-04-2018-0026.

[22] Musyafah, A. A. (2019). Peran Otoritas Jasa Keuangan (OJK) Dalam Hal Perlindungan Nasabah Pada Lembaga Keuangan Mikro Syariah. Law, Development and Justice Review, 2(2), 194-211.

[23]Nasution, A. (2017). Sekilas Hukum Perlindungan Konsumen. Jurnal Hukum \& Pembangunan, 16(6), 568-581.

[24] Nasruddin, R., \& Haq, I. (2020). Pembatasan Sosial Berskala Besar (PSBB) dan Masyarakat Berpenghasilan Rendah. SALAM: Jurnal Sosial dan Budaya Syar-i, 7(7), 639648.

[25] Nursamsi, D. (2014). Kerangka Cita Hukum (Recht Idee) Bangsa Sebagai Dasar Kewenangan Mahkamah Konstitusi Menguji Peraturan Pemerintah Pengganti UndangUndang (Perppu). Jurnal Cita Hukum, 2(1).

[26] Rahmayani, N. (2018). Tinjauan Hukum Perlindungan Konsumen Terkait Pengawasan Perusahaan Berbasis Financial Technology di Indonesia. Pagaruyuang Law Journal, 2(1), 24-41.

[27]Ringe, W. G., \& Christopher, R. U. O. F. (2020). Regulating Fintech in the EU: the Case for a Guided Sandbox. European Journal of Risk Regulation, 11(3), 604-629.

[28]Rosenblum, R. H., Gault-Brown, S. A., \& Caiazza, A. B. (2015). Peer-to-peer lending platforms: Securities law considerations. Journal of Investment Compliance, 16(3), 15-18. Doi.Org/10.1108/Joic-06-2015-0038.

[29] Saija, R., \& Sudiarawan, K. A. (2021). Perlindungan Hukum Bagi Perusahaan Debitur Pailit dalam Menghadapi Pandemi Covid 19. Batulis Civil Law Review, 2(1), 66-77.

[30] Saksonova, S., \& Kuzmina-Merlino, I. (2017). Fintech as Financial Innovation-The Possibilities and Problems of Implementation. European Research Studies Journal, 20(3), 961-973. 
[31] Spoorthy, M. S., Pratapa, S. K., \& Mahant, S. (2020). Mental health problems faced by healthcare workers due to the COVID-19 pandemic-A review. Asian journal of psychiatry, 51, 102119.

[32] Syafriana, R. (2017). Perlindungan konsumen dalam transaksi elektronik. De Lega Lata: Jurnal Ilmu Hukum, 1(2), 430-447.

[33] Taun, T., \& Nugraha, A. (2020). Penerapan Hukum dalam Pemutusan Hubungan Kerja dan Kebijakan Bank Terhadap Debitur yang Terdampak Pandemi Covid-19. Batulis Civil Law Review, 1(1), 24-32.

[34] Treleaven, P. (2015). Financial Regulation of FinTech. Journal of Financial Perspectives, 3(3), 114-121.

[35] Widijantoro, J. (2019). The Role of Financial Services Authority in The Consumer Protection Amid The Growth of Fintech Industry in Indonesia. Mimbar Hukum-Fakultas Hukum Universitas Gadjah Mada, 31(2), 297-308.

[36] Yuking, A. S. (2018). Urgensi peraturan perlindungan data pribadi dalam era bisnis fintech. Jurnal Hukum dan Pasar Modal, 8(16), 1-27.

\section{Buku}

[37] Raharjo, S. (2017). Membedah Hukum Progresif, Jakarta: Penerbit Kompas.

[38] Soekanto, S. (2012), Pengantar Penelitian Hukum, Jakarta: Universitas Indonesia Press.

\section{Online/World Wide Web, Disertasi dll}

[39] Akbar, C. (2019). Lagi, OJK Temukan 297 Layanan Pinjaman Online Ilegal. Retrieved from https://bisnis.tempo.co/read/1266896/lagi-ojk-temukan-297-layanan-pinjamanonline-ilegal.

[40] Carmona, A. F., Lombardo, A. G. Q., Pastor, R. R., Quirós, C. T., García, J. V., Muñoz, D. R., \& Martin, L. C. (2018). Competition issues in the area of financial technology (Fintech). Policy Department for Economic, Scientific and Quality of Life Policies of the European Parliament. Working Paper, Directorate General For Internal Policies Policy Department A: Economic And Scientific Policy, European Parliament.

[41]Daftar Fintech Berijin dan Terdaftar di OJK. https://www.ojk.go.id/id/kanal/iknb/financialtechnology/Default.aspx.

[42]Data Fintech illegal, Berdasarkan Rilisan Otoritas Jasa Keuangan Per 4 Mei 2021. https://www.ojk.go.id/id/Default.aspx.

[43] Ehrentraud, J., Ocampo, G. D., Garzoni, L., \& Piccolo, M. (2020). Policy responses to fintech: a cross-country overview, BIS, Financial Stability Institute. Insight on policy implementation, (23).

[44] Hidayat, R. (2019). Dpr Terbuka Jika Industri Fintech Diatur Uu, Tapi.... Retrieved From Https://Www.Hukumonline.Com/Berita/Baca/Lt5c9e0b2aec3ed/Dpr-TerbukaJikaindustri-Fintechdiatur-Uutap.

[45] Koonprasert, T., \& Mohammad, A. G. (2020). Creating Enabling Fintech Ecosystems: The Role of Regulators. AfI Special Report, 2020-01.

[46]Perkembangan Covid-19. https://covid19.go.id.

[47] Santoso, W. (2020, March). Fintech and the future of finance. In International Seminar on Fintech and The Future of Finance (Vol. 12).

[48] Sari, F. (2019). Perjelas Landasan Hukum, Ojk Dorong Pembentukan Uu Fintech. Retrieved From Https://Keuangan.Kontan.Co.Id/News/Perjelas-Landasanhukum-OjkDorong Pembentukan-Uu-Fintech.

[49] Wulandhari, R. (2019). Afsi: Peraturan Ojk Belum Mewadahi Fintech Syariah. Retrieved From Https://Republika.Co.Id/Berita/Pwmq1n370/Afsi-Peraturan-Ojkbelum-MewadahiEmfintechem-Syariah. 